\title{
EFL Reading Comprehension Textbooks at University Level: A Critical Thinking Perspective
}

\author{
Mohammad Reza Talebinezhad \\ Islamic Azad University, Shahreza Branch, Iran \\ Email: rtalebinezhad@yahoo.com \\ Zahra Matou \\ Shaikhbahee University, Iran \\ Email: Zahra.Matou56@yahoo.com
}

\begin{abstract}
In line with the studies in EFL/ESL contexts confirming the positive relationship between critical thinking ability and reading comprehension, this study intended to investigate how frequently critical thinking is used in EFL Reading Comprehension textbooks at university level in Iran. The study investigated the course books used in order to understand to what extent critical thinking is advocated in such books. To this end, all question types in general and Critical Reading Questions (CRQs), Vocabulary In Context (VIC), Literal Comprehension (LC), and Extended Reasoning (ER), in particular were identified. The focus of the study was on ER questions, leading to critical thinking. The reason was that the crucial problem of the students lies in textually implicit information of the texts, that is, ER questions. To classify the questions for CRQs, Peterson`s (2008) model was employed, and to specify critical thinking question types, a framework proposed by Academic Skills Unit (2008) was used as reference. To collect the data entirely, the researcher identified the total number of percentages of frequencies of questions related to the passages in the course books of Reading Comprehension I, II and III. The findings seem to indicate high attention to critical thinking within the objectives of the questions of their course books and the authors of the passages.
\end{abstract}

Index Terms - critical thinking, EFL reading comprehension textbooks, Iranian university level, Peterson's 2008 Model and Academic Skills Unit (2008) Framework

\section{INTRODUCTION}

Critical thinking seems to be one of the noticeable issues in education during the recent decades. Critical thinking skills figure prominently among the goals for education, whether one asks developers of curricula, educational researchers, parents, or employers (Beyer, 1985). Problem-finding can be a good opportunity to share whatever all of the students and their teachers know not only in math, physics and other sciences but also in language learning.

A number of different strategies have been used for language learning. Critical thinking has been viewed as a useful strategy. Generally speaking, critical thinking in reading turns to an issue which pertains to the present study: an investigation of EFL reading comprehension textbooks at university level from a critical thinking perspective. Given that learning a new language demands flexibility and higher-order thinking skills (Liaw, 2007), critical thinking can contribute to their academic success.

Today, making students more conscious of and responsible for their own knowledge and thought is highly emphasized. The textbook plays an important role in English Language Teaching (ELT), particularly in the English as a Foreign Language (EFL) classroom where it provides the primary form of linguistic input (Kim and Hall, 2002). Nowadays, EFL/ESL researchers have paid attention to critical thinking as a process in developing reading skill. For the students to make sense out of the written text, their interaction with the text is required. For this interaction, Nist and Mealey (1991) believe that metacognition in reading tasks is the most influential.

\section{Statement OF The PRoblem}

The reading skill plays a significant role in language learning classes. Language learners read the texts to understand not only unknown words but also the meaning of the whole sentence. But this is not the only aim of reading the passages. It is expected especially from the higher level students to go beyond the sentences, that is, get the intended meanings of the writers.

However, each passage has certainly hidden ideas and messages which should not be ignored. To consider this matter, Schooten and Glopper (2003) state that the focus of many studies has changed from the writer of the text to the reader or the interaction between reader and text. To improve the students` ability to reason demands "finding information that is not directly stated in the passage" (Peterson`s, 2008, P.124). Clearly, the more emphasis is on learners and learning also "the processes through which learning takes place" (Oxford, 2001). Rubinstein and Firstenberg, Lochhead and Whimby, and Wood (1987) have proposed a solution to deal with this problem. They recommend that better thinking 
should be taught explicitly for transfer across academic domains.

In this respect, a number of investigations have been conducted on the relationship between critical thinking and the reading ability of university students. These studies aim at having better language learning or more success in EFL contexts. The main reason for the present research stems from the fact that the notion of critical thinking and reading comprehension as well as their relationship with second language learning is considered to be important and recent matter in Iran. The researcher attempts to the feasibility of helping Iranian academic EFL students to become more critical readers through inferring the intended meaning of the text.

\section{RESEARCH QUESTION}

This study investigated the different kinds of Critical Reading Questions, CRQs, in three course books of Reading Comprehension I, II and III.

To meet this objective, the following research question was formulated. _To what extent do the questions of ELT reading comprehension textbooks at the university in Iran follow the objectives of such texts concerning critical thinking?

\section{LITERATURE REVIEW}

Recent trends within the domain of reading comprehension have led to an increasing emphasis on the role of problem-solving techniques that supposedly enable students to identify, clarify, evaluate and solve perplexities that arise in reading (Waters, 2006). In this respect, various definitions of critical thinking and its significance in educational system, language learning especially reading skill which is the focus of this study have been proposed.

\section{A. Definitions of Critical Thinking}

In the 1980s, there was an outburst of interest in critical thinking (Dam, Vloman, and Wardekker, 2004). Many researchers have attempted to offer satisfactory definitions of critical thinking. Regarding diverse definitions of critical thinking, Beyer (1985) states that nearly all emphasize the ability and tendency together, evaluate and use information effectively. The emergence of these different definitions is due to its cognitive nature in which critical thinking is seen as an "ongoing activity" (Canagarajah, 2002, p. 101).

Critical thinking is defined as a cognitive ability compounded with multiple skills such as identifying, understanding, and analyzing an issue by deploying inferences using top-down and bottom-up strategies to validate the reliability of claims and arguments. (Pithers and Soden, 2000). Gabennesch (2006) puts it in this way: "Critical thinking is the use of rational skills, worldviews, and values to get as close as possible to the truth" (pp. 36-41).

In the same vein, Liaw (2007) defines critical thinking as something which "involves the use of information, experience, and world knowledge in ways which allow [EFL students] to seek alternatives, make inferences, pose questions, and solve problems, thereby signaling understanding in a variety of complex ways" (p. 51).

Finally, Rubenfeld and scheffer (2010) consider critical thinking the metaphorical bridge between information and action. They mention three reasons that "this bridge is invisible from one perception into something visible from a new perspective" (p. 26). These authors think that critical thinking is tangible, very individual, and requires effort today not tomorrow.

\section{B. Components of Critical Thinking}

To McPeck (1981, as cited in Simpson, 2002) critical thinking involves both a propensity and skill. It would appear that the affective and the cognitive domains of reasoning play significant roles to be a critical thinker. Recognizing McPeck`s work, Simpson (2002) has developed the idea that these two components can be shaped as: "(i) the context of discovery and (ii) the context of justification" (p. 7).

The website of ASME PPC Online summarized a range of ideas referring to the components of critical thinking. As its authors argue, the eight components that have been identified as part of the critical thinking process include:

1. Perception: refers to the way we receive and translate our experiences.

2. Assumption: underlie the ideas, beliefs, values, and actions that others and we take.

3. Emotion: separates humans from machines and the lower animals.

4. Language: carries the content and structures the form of the entire thinking process.

5. Argument: is simply a claim, used to persuade others that something is (or is not) true and should (or should not) be done.

6. Fallacy: is an incorrect pattern of reasoning.

7. Logic: Induction and deduction are two different processes of logical reasoning with different levels of conclusiveness.

8. Problem Solving: Solving "logic" problems is like solving any problem that we encounter or identify in life.

\section{Educational Significance of Critical Thinking}

Critical thinking has attracted the attention of educators over the past decades. The significance of critical thinking in education and particularly higher education is now acknowledged by a large number of educators. Schafersman (1991) 
asserts that all education must involve not only "what to think", but also "how to think". Students should be assisted in engaging in a type of thinking that is reflective, reasonable and directed on what to believe or do (Ennis, 1962, as cited in Simpson, 2002).

Academically successful learners possess problem-solving, analytical, and critical thinking skills (De Boo, 1999; Gardner and Jewler, 2000). In the same domain, Constructivists, like cognitive psychologist, look at learning as a perception process, resulted from experience, and believe that executives of lesson plans should provide a situation that students, via reasoning debates which facilitate and accelerate interaction and analysis action, do critical thinking (Zahorik, 1995). Hence, critical thinking is a necessary skill in promoting the students' thoughts.

Finally, Moon (2008) asserts that critical thinking and its relationship to the educational process has become a central issue and it is time to explore the term. She adds since critical thinking is a process which is involved in any research activity; it can be considered as a principal concept to education, especially at higher levels. In fact, it is a fundamental goal of learning.

\section{Critical Thinking Significance in Language Learning}

Clearly, language and thought are closely related. Language permits thoughts to be represented in our minds, helping us reason, plan, remember, and communicate. It is communication that gets all the press when we talk about language, but there are also questions to be asked about whether the language we use causes us to think in a certain way (Huddleston and Pullum, 2005). It is strongly believed that higher-order thinking skills especially critical thinking should be an integral part of L2 curriculum to foster language proficiency of the EFL/ESL learners (Davidson, 1998; Chamot, 1995 as cited in Liaw, 2007).

The aim for critical language awareness in an educational context is what Van Lier and Corson (1997) state: "to achieve some critical distance on familiar practices in order to better understand the unfamiliar - to make the familiar strange and the strange familiar in ethnographic terms" (p. 245). Learning to thinking critically can produce enthusiastic language learners. Marshall and Rowland (1998) describe how critical thinking produces "joy, release, relief, and exhilaration as we break through to new ways of looking at our personal, work, and political worlds" (p. 34).Alan and Stoller (2005) stress that, to best facilitate learning of language, content and real-life skills, projects "require a combination of teacher guidance, teacher feedback, students engagements, and elaborated tasks with some degree of challenge" (p. 11).

\section{E. Critical Thinking in Reading}

Rivers (1981) elaborates that "a reading is a most important activity in any language class, not only as a source of information and a pleasurable activity, but also as a means of consolidating and extending one's knowledge of the language" (p. 259). The ability to read is the most stable and durable of the second language modalities (Bernhardt, 1991). In language teaching, reading is recognized as an activity that engages students more actively with materials in the target language and encourages a deeper processing of it, since it is considered to be a communicative process which conveys meaning from writer's to the reader's mind (Nuttal, 1996).

Researchers have reported that college students with lower verbal ability were able to identify individual words and facts but were unable to combine the information in the text with the previously acquired information (Baker, 1985). This inability to integrate ideas was accompanied by an inability to draw logical inferences and the inability to check ideas while reading to see if the ideas contradicted one another (Baker, 1985). Brown and Day (1983) reported that Junior college students and college students were unable to summarize, select the topic sentence, and invent a topic sentence if it was implied, or write a synopsis of a paragraph in the absence of explicitly stared topic sentence.

The primary goal of the reading tasks in many studies is to further develop and clarify interpretation of the text, and to help students remember what they have individually created in their minds from the text (Phan, 2006; Willinghah, 2006). "Reading is not merely a receptive process of picking up information from the page in a word-by-word manner" (Grabe, 1991, p. 1). Rather, it is a selective process and characterized as an active process of comprehending. The degree by which a passage or text is understood is called reading comprehension (Pakhare, 2007; Phan, 2006).

In this respect, McNamara (2007) also contends that Reading Thinking "(RT) is a well-validated approach to improving students`comprehension and self-monitoring skills through an apprenticeship model of learning" (p. 425). He asserts that "The teacher and students engage in an instructional dialogue about the text, constructing their understanding of the text as they apply several strategies: predicting, questioning, summarizing, and clarifying" (p. 425).

Further, with active reading tasks, readers encourage to voice their own opinions about the text and discuss those opinions with other students and the teacher. Another advantage of such tasks is that they contextualize reading, that is, they allow the readers to see the text as part of a broader social context that includes the writer and the readers (Tomitch, 2000). In addition, "students who have effective reading strategies can engage in higher thinking skills about texts and their relations to those texts" (National Reading Panel, 2000 cited in Hernàndez-Laboy, 2009, p. 4).

From Paul and Elder`s (2006) viewpoint, to read well requires one to develop one's thinking about reading and, as a result, to learn how to engage in the process of what we call close reading. Their viewpoint deals with the active use of intellectual skills. They recommend that Students not only need to learn how to determine whether a text is worth reading, but also how to take ownership of a text's important ideas (when it contains them). 


\section{F. Role of Materials}

Sweet and Snow (2003) consider the process of extracting and constructing meaning from text as reading comprehension on which three interactive elements impact: the reader, the text, and the context. Thus, in helping learners to be better readers one is material or whatever they read. Johnson and Johnson (1998) claim "...interest is not independent of the text, and if the text does not meet readers' expectations (for example, if it is too long) then interest will diminish" (p.132). Tomlinson (2001) explains that the study of materials development was not given any real importance until the 1990s when books on this subject started to be published.

In selecting materials from foreign countries, teachers should be sensitive to decide whatever the use in the classroom. As Bishop, Bishop and Gentile (2009) state: "Students are best motivated to use and practice their skills with material that is interesting and relates to something that really want to learn" (p. 128). "The subject matter must relate to the world, to students' own position and that of others, and to students 'opportunities to influence this position" (Dam and Volman, 2004, p. 373). Textbooks play a vital role in many language classrooms and after teachers they are considered to be the next important factor in the second/foreign language classrooms (Riazi, 2003).

In this way, Flippo and Carerly (2008) hold that: "clear distinction has to be made in terms of the shift from reading didactic college textbooks to trade books whose main role is to provoke argumentation at various levels, so that students arrive at personally as well as contextually defined understandings and conclusions regarding the material" (p. 27).

One strategy that can benefit language learning is taking a thoughtful approach to material development. This is especially true for the EFL context, where the classroom is often the only source of English, and materials "play a crucial role in exposing learners to the language" (Dudley-Evens and St. John 1998, p. 171). "Many sources have an ideological bias, especially the "think tanks." You need to read their statements about their philosophy and also check other sources to make sure you are not getting a one-sided point of view." (Burke, 1988, rev. 2003, p. 4).

Huckin (1997) emphasizes the importance of assigning reading material that pertains to a subject and culture with which students are familiar. Such material can often be found in English-language newspapers and magazines that deal with topics of local interests. From Moorman and Ram`s (1994) point of view, "stories offer many opportunities for creative reading" (p. 646).

To accomplish certain goals of textbooks on critical reading, Kurland (2000) elaborates that these texts commonly ask students to:

- recognize an author`s purpose.

- understand tone and persuasive elements.

- recognize bias.

"One response to the overwhelming amount of material found in modern introductory textbooks is to emphasize process over content by trying to shape critical thinking in students taking their first psychology course" (Benjamin, Brewer and Hebl, 2000, p. 25). By process, they focus "to improve critical thinking skills in students, to send them out of [the] class as a more sophisticated processor of information as a worker, employer, spouse, parent, television viewer, medical patient, newspaper reader, and so forth" (p. 25).

Regarding the critical thinking basis for test use in subject matter, Yeh (2001) believes:

A valid test item might present source material containing data, evidence or examples, perhaps with conflicting views about how to interpret, synthesize, analyze, or evaluate the material, and ask respondents to construct a strong argument or select the strongest argument that also addresses important counterarguments (p.14).

Such a test would aim encouraging behaviors on the part of administrators, teachers, and students that encourage the learning of desirable critical thinking skills (Frederiksen and Collins, 1989). In the same vein, Messick (1989) argues that a systemically valid test leads to good educational practices and worthwhile learning; a systemically invalid test leads to ineffective or corrupt educational practices.

Of a broad critical literacy education for twenty-first century, Wallace (2003) has proposed: "Texts were drawn from a wide range of community sources: letters through the mail, advertisement, poster taken from billboard political manifests, travel brochures and newspaper material of various kinds" (p. 106). He added that in making practical choices relating to syllabus content, cultural and ideological factors are implicated as well as linguistic difficulty and it is teacher's role to decide on the use of these books and put them into text sets.

Willsen and Binker (1993) also illuminated the point that:

Everywhere there are systems inherent in subject matter, networks of logically ordered parts functioning in relation to each other for a definite human purpose. Critical thinking, with its system-unlocking orientation, is the perfect set of tools to take command of the systems inherent in subject matter (p. 34).

"To become competent language users and learners, students must develop knowledge and understanding of different texts and how these are influenced by context (purpose, audience, channel of communication and content)" (Mawter, 2007, p. 5). Accordingly, this author emphasizes on thinking critically about a wide range of spoken, written, graphic, and performance texts and comes to conclude that "students will learn how language functions and how texts reflect and shape social attitudes and structures" (p. 5).

Choosing material should be taken into account to find, analyze, synthesize and evaluate information. Such information from "a credible and unbiased source is increasingly essential in the modern world, whether it is found in a book, on a CD-ROM, or online. Informational literacy is an important part of critical thinking, which is the ability to 
judge the authenticity, accuracy, and worth of information" (Montte, Sullivan, and DeJong, 2010, p. 495). For college students, they have promulgated "reference librarians are useful long after those years to help find and analyze information about social issues or personal problems and to help people keep current in their chosen fields of endeavor" (p. 495).

"Even the addition of a sort "critical thinking exercise" to be completed at the end of each class enhances critical thinking development and allows the students to practice analysis of ideas presented, values and attitudes revealed, and self-reflection" (Masters, 2005, p. 88). In this case, she has paid particular attention to dividing the class into groups and points out small group analysis instead of individualized critical thinking can bedeveloped to increase team consensus with more emphasis on critical thinking.

\section{RESEARCH METHOD}

\section{A. Research Design}

In this type of research method, written materials were analyzed for the purpose of identifying Critical Reading Questions. Using a coding scheme, all units from above-mentioned course books were chosen in terms of the objectives of the questions concerning critical thinking.

\section{B. Materials}

The materials of the current study were three textbooks of Reading Comprehension courses I, II, III. The course books named 'Communicative Reading Skills' by Akbar Mirhassani and Mohammad Alavi (2008) for Reading comprehension I, 'Effective Reading', for advanced students, by Simon Greenall and Michael Swan (1988) for Reading comprehension II, and 'Active Book 4' by Neil j. Anderson (2001) for Reading comprehension III. These books were taught in one of the universities in Isfahan. These course books provide some reading passages from authentic sources as well as preceding and following exercises to involve learners in the activities. All the three textbooks do not follow a similar pattern.

\section{Coding Scheme and Analysis Procedures}

Carefully studying the definitions of Peterson`s 2008 model and the guidelines laid down by Academic Skills Unit (20080, the researcher adopted the above-mentioned expanded definition in counting the frequency of critical reading questions in the present study. In other words, Vocabulary-In-Context (VIC) questions test the learners` ability to define difficult and unfamiliar words and Literal Comprehension (LC), questions usually address information which can be found directly in the passage. In Extended Reasoning (ER) questions, learners have the opportunity to react, for example, by simply making an inference and combining story or context clues with what they already know to find unstated information. Hence, the last type of questions permits students to foster the application of critical thinking.

Following the above- mentioned categorization, the data were subjected to a detailed analysis. In so doing, the researcher adopted a frame work for critical thinking which has been suggested by Academic Skills Unit (2008). In this framework there are a number of guidelines to become better critical thinkers. The following are taken from Academic Skills Unit (2008) as examples of each category:

.Clarity: could you elaborate further on that point? Could you express that point in another way? Could you give an illustration?

- Accuracy: Is that really true? How could we check that? How could we find out if that is true?

- Precision: Could you give more details? Could you be more specific?

- Relevance: How is that connected to the question? How does that bear on the issue?

- Depth: How does your answer address the complexities in the question? How are you taking into account the problems in the question?

- Breadth: Do you need to consider another point of view? Is there another way to look at this question? What would this look like from a conservative standpoint?

. Logic: Does this really make sense? Does that follow from what you said?

(ASU, 2008, pp. 112-113).

The rationale behind such selections of model and framework was their comprehensiveness and being recent. The results are presented in the following section. The data for this study which were mainly questions and exercises related to the passages were first codified. This study was a qualitative type of research; however, some quantitative analysis was done for computing the frequency of each type of CRQs in Peterson`s 2008 Model.

\section{RESULTS AND DISCUSSIONS}

Initially, descriptive statistics were carried out for reading comprehension questions involved in this study. The results are reported in the following tables. The questions were divided into three types: Vocabulary In Context (VIC), Literal Comprehension (LC) and Extended Reasoning (ER). The following tables present the number of frequencies and percentages of all CRQs which were found in the afore-mentioned books. F and P were used to show frequency and percentage respectively. 
TABLE 1:

TYPES OF CRITICAL READING QUESTIONS AND EXERCISES IN THE COURSE BOOK OF READING COMPREHENSION 1

\begin{tabular}{|c|c|c|c|c|c|c|}
\hline \multirow{2}{*}{$\begin{array}{ll}\text { Exercises } & \text { Types of CRQs }\end{array}$} & \multicolumn{2}{|c|}{ VIC } & \multicolumn{2}{|l|}{$\mathrm{LC}$} & \multicolumn{2}{|l|}{ ER } \\
\hline & $\mathrm{F}$ & $\mathrm{P}$ & $\mathrm{F}$ & $\mathrm{P}$ & $\mathrm{F}$ & $\mathrm{P}$ \\
\hline Discussion Questions & - & - & - & - & 39 & $22.41 \%$ \\
\hline Reading Questions & - & - & - & - & 23 & $13.21 \%$ \\
\hline $\begin{array}{l}\text { How well did you } \\
\text { Read? }\end{array}$ & - & - & 25 & $14.36 \%$ & - & - \\
\hline $\begin{array}{l}\text { Understanding } \\
\text { Organization }\end{array}$ & - & - & - & - & 2 & $.14 \%$ \\
\hline Scanning fr Details & - & - & 3 & $1.72 \%$ & - & - \\
\hline Figure It Out & 6 & $3.44 \%$ & - & - & - & - \\
\hline Making Inferences & - & - & - & - & 2 & $1.14 \%$ \\
\hline Making Predictions & - & - & - & - & 2 & $1.14 \%$ \\
\hline Reading the Articles & - & - & 1 & $0.57 \%$ & & \\
\hline $\begin{array}{l}\text { Understanding the } \\
\text { Article }\end{array}$ & - & - & - & - & 2 & $1.14 \%$ \\
\hline $\begin{array}{l}\text { Application of } \\
\text { Information }\end{array}$ & - & - & 2 & $1.14 \%$ & 3 & $1.72 \%$ \\
\hline $\begin{array}{l}\text { Building Vocabulary } \\
\text { Skills }\end{array}$ & 1 & $0.57 \%$ & - & - & - & - \\
\hline Using Abbreiation & & & & & 1 & $0.57 \%$ \\
\hline Just For Fun & 1 & $0.57 \%$ & 2 & 1.14 & 4 & $2.28 \%$ \\
\hline Oral Reports & - & - & - & - & 1 & $0.57 \%$ \\
\hline Reader`s Journal & - & - & - & - & 8 & $4.59 \%$ \\
\hline $\begin{array}{l}\text { Interpreting The } \\
\text { Article }\end{array}$ & - & - & - & - & 1 & $0.57 \%$ \\
\hline $\begin{array}{l}\text { Identifying Main } \\
\text { Idea }\end{array}$ & - & - & 2 & $1.14 \%$ & 5 & $2.87 \%$ \\
\hline Examining Effects & - & - & - & - & 1 & $0.57 \%$ \\
\hline Examining Solutions & - & - & - & - & 1 & $0.57 \%$ \\
\hline $\begin{array}{l}\text { Recalling } \\
\text { Information }\end{array}$ & - & - & 2 & $1.14 \%$ & - & - \\
\hline $\begin{array}{l}\text { Understanding the } \\
\text { Interview }\end{array}$ & - & - & - & - & 1 & $0.57 \%$ \\
\hline Informal Language & 1 & $0.57 \%$ & - & - & - & - \\
\hline $\begin{array}{l}\text { Understanding The } \\
\text { Structure }\end{array}$ & - & - & - & - & 1 & $0.57 \%$ \\
\hline $\begin{array}{l}\text { Distinguishing Fact } \\
\text { From Opinion }\end{array}$ & - & - & - & - & 1 & $0.57 \%$ \\
\hline $\begin{array}{l}\text { Distinguishing Main } \\
\text { Ideas From } \\
\text { Supporting Points }\end{array}$ & - & - & - & - & 1 & $0.57 \%$ \\
\hline $\begin{array}{l}\text { Comprehension } \\
\text { Check }\end{array}$ & - & - & - & - & 1 & $0.57 \%$ \\
\hline Locating Information & - & - & 1 & $0.57 \%$ & - & - \\
\hline Synonyms & 2 & $1.14 \%$ & - & - & - & - \\
\hline Writing Titles & - & - & - & - & 5 & $2.87 \%$ \\
\hline Proverbs & - & - & - & - & 2 & $1.14 \%$ \\
\hline $\begin{array}{l}\text { Recognizing Main } \\
\text { Ideas }\end{array}$ & - & - & - & - & 2 & $1.14 \%$ \\
\hline Summarizing & - & - & - & - & 4 & $2.29 \%$ \\
\hline Previewing & - & - & - & - & 1 & $0.57 \%$ \\
\hline $\begin{array}{l}\text { Understanding Point } \\
\text { of View }\end{array}$ & - & - & - & - & 1 & $0.57 \%$ \\
\hline Idioms & 1 & $0.57 \%$ & - & - & - & - \\
\hline Matching & - & - & 1 & $0.57 \%$ & - & - \\
\hline $\begin{array}{l}\text { Finding Support For } \\
\text { Main Ideas }\end{array}$ & - & - & - & - & 3 & $1.72 \%$ \\
\hline $\begin{array}{l}\text { Expanding } \\
\text { Vocabulary }\end{array}$ & 4 & $2.29 \%$ & - & - & - & - \\
\hline Encyclopedia Article & - & - & - & - & 1 & $0.57 \%$ \\
\hline Read and React & - & - & - & - & 1 & $0.57 \%$ \\
\hline Total & 16 & $9.1 \%$ & 39 & $22.3 \%$ & 120 & $68.6 \%$ \\
\hline
\end{tabular}

The overall number of different types of CRQs indicated that in this book there were 120 (69.68 \%) ER questions, 39 (22.45\%) LC and 16 (9.15\%) VIC. ER questions were more frequently than LC and VIC questions in this course book.

Table 2 shows the frequencies and percentages of CRQs in the course book which have been taught in all Reading Comprehension course II. 
TABLE 2:

TYPES OF CRITICAL READING QUESTIONS AND EXERCISES IN THE COURSE BOOK OF READING COMPREHENSION 2

\begin{tabular}{|c|c|c|c|c|c|c|}
\hline \multirow{2}{*}{$\begin{array}{ll}\text { Exercises } & \text { Types of CRQs } \\
\end{array}$} & \multicolumn{2}{|c|}{ VIC } & \multirow{2}{*}{\begin{tabular}{|l|l} 
\\
\end{tabular}} & \multirow{2}{*}{$\begin{array}{ll}\mathrm{LC} \\
\mathrm{P}\end{array}$} & \multicolumn{2}{|l|}{ ER } \\
\hline & $\mathrm{F}$ & $\mathrm{P}$ & & & $\mathrm{F}$ & $\mathrm{P}$ \\
\hline $\begin{array}{l}\text { Extracting Mai } \\
\text { Ideas }\end{array}$ & - & - & 2 & $0.98 \%$ & 27 & $13.23 \%$ \\
\hline $\begin{array}{l}\text { Reading for Specific } \\
\text { Information }\end{array}$ & - & - & 9 & $4.41 \%$ & - & - \\
\hline $\begin{array}{l}\text { Understanding } \\
\text { Text Organization }\end{array}$ & & - & - & - & 20 & $9.80 \%$ \\
\hline Predicting & - & - & - & - & 13 & $6.37 \%$ \\
\hline Checking Comprehension & - & & 6 & $2.94 \%$ & 3 & $1.47 \%$ \\
\hline Inferring & - & - & - & - & 24 & $11.76 \%$ \\
\hline $\begin{array}{l}\text { Dealing with } \\
\text { Unfamiliar Words }\end{array}$ & 27 & $13.23 \%$ & - & - & - & - \\
\hline Linking Ideas & - & - & - & - & 10 & $4.90 \%$ \\
\hline $\begin{array}{l}\text { Understanding } \\
\text { Complex Sentences }\end{array}$ & - & - & 4 & $1.96 \%$ & 4 & $1.96 \%$ \\
\hline $\begin{array}{l}\text { Understanding } \\
\text { Writer`s Style } \\
\end{array}$ & - & - & - & - & 15 & $7.35 \%$ \\
\hline Evaluating the Text & - & - & - & - & 9 & $4.41 \%$ \\
\hline Reacting to the Text & - & - & - & - & 4 & $1.96 \%$ \\
\hline Writing Summaries & - & - & - & - & 27 & $13.23 \%$ \\
\hline Total & 27 & $13.2 \%$ & 21 & $10.3 \%$ & 156 & $76.5 \%$ \\
\hline
\end{tabular}

The data in Table 2 show that there were 156 (76.44\%) ER questions, 21 (10.29\%) LC and 27 (13.13\%) VIC. The difference of the number of frequencies of CRQs is statistically significant. It means that the highest percentage belongs to ER questions.

Table 3 illustrates the frequencies and percentages of different types of CRQs in the course book of Reading Comprehension III.

TABLE 3:

FREQUENCIES AND PERCENTAGES OF CRQS IN THE COURSE BOOK OF READING COMPREHENSION III

\begin{tabular}{|l|l|l|l|l|l|l|}
\hline \multirow{2}{*}{ Exercises } & Lypes of CRQs & VIC & P & F & ER & F \\
\cline { 2 - 7 } & F & - & - & - & - & 12 \\
\hline $\begin{array}{l}\text { Skimming for } \\
\text { Content }\end{array}$ & - & - & 12 & $25 \%$ & - \\
\hline $\begin{array}{l}\text { Checking } \\
\text { Understanding }\end{array}$ & - & - & 12 & $25 \%$ & - \\
\hline Critical Thinking & - & - & - & - & \\
\hline Total & - & - & 24 & $50 \%$ & 12 \\
\hline
\end{tabular}

As depicted in Table 3, there were no questions of VIC. 50\% LC and ER questions were identified respectively in this course book.

The number of Critical Reading Questions in course books of Reading Comprehension I and II represent a substantial discrepancy in the frequency of CRQs. With regard to the proportion of different types of CRQs in the above-mentioned course books, the frequencies of ER are remarkably higher than that of VIC and LC Questions. Results in Reading comprehension III revealed a statistically equal number of frequencies of LC and ER questions. The format of the questions in all units of these textbooks are to large extent the same. Qualitative findings are presented in the following section to interpret and justify the findings on the frequency of CRQs type based on the question objectives of the textbooks.

\section{CONCLUSIONS}

To address the research question all the exercises of the afore-mentioned course books were considered. The objective was to see to what extent these books advocate critical thinking. Tables 1 and 2 show that the numbers of ER questions were very high in contrast to other types of CRQs in the course books. It is in accord with what Peterson`s (2008) argues, "most of the critical reading questions involve extended reasoning" (p. 119). Such evidence may prove that the exercises or questions of those course books can be regarded as useful means to promote critical thinking. In the textbook of Reading Comprehension III, since some vocabulary items followed by explanations written after each unit, no VIC questions were included in the book. It also provides the students with proper and fruitful exercises which foster the application of ER questions. According to Table 3, by means of 50 percent LC questions and 50 percent ER questions, the students are able to communicate and interact with their teacher and other students at the higher level .Clearly, literal comprehension influences reading comprehension. In this connection, Adams and Patterson (2007) claim that it is the most basic level of understanding, providing the foundation for the development of the higher level, namely, critical comprehension. 
Seemingly, students especially college students as higher level thinkers are very much in need of invoking critical thinking in the ever-changing world. Concerning reading skills, the students should be helped to improve their skills in understanding details and specific information. Critical thinking activities at different levels of language proficiency in English language classrooms can increase learners`current level of thinking and simultaneously grasp the main meaning of the text (Waters,2006).

Finally, it is hoped that the findings related to critical thinking and language learning will encourage the well-planned instruction of critical thinking and problem solving in EFL contexts. Solving problems, evaluating what has been read, and integrating understanding with knowledge of the world are considered as the various goals of reading (MCPeck, 1991).

\section{REFERENCES}

[1] Academic Skills Unit, (2008). The ACU Study Guide (6 ${ }^{\text {th }}$ ed). Sydney: ACU.

[2] Adams, R. W., \& Patterson, B. (2007). Developing Reading Versality. Cengage Learning.

[3] Alan, B., \& Stoller, F. L. (2005). Maximizing the Benefits of Project work in Foreign Language Classrooms. English Teaching Forum. 43 (4), 10-21. ASME Professional Practice Curriculum at http://professional practice.asme.org

[4] Baker, L. (1985).Differences in the standards used by college students to evaluate their comprehension of expository prose. Reading Research Quarterly. 20 (3), 297-313.

[5] Benjamin, L. T., Brewer, Ch. L., \& Hebl, M. R. (2000). Handbook for teaching introductory psychology, Volume 2. New York: Routledge.

[6] Bernhardt, E. (1991). Reading Development in a Second Language. New York: Ablex.

[7] Beyer, B. K. (1985). Critical thinking: What is it? Social Education. 49 (4), 270-276.

[8] Bishop, A., Bishop, S., \& Gentile, L. M. (2009). Teaching Word Analysis Skills. Shell Education.

[9] Burke, C. G. (1988). What is Critical Thinking? Retrieved September, 2003 from http://www.usc.edu/schools/sppd/private/documents/doctoral/critical thinking.pdf

[10] Brown, A. L., \& Day, J. J. (1983). Macro rules for summarizing texts: development of expertise center for the study of reading (Tech. Rep. No. 270). Urbana: University of Illinois.

[11] Canagarajah, A. S. (2002). Critical academic writing and multilingual students. Ann Arbor, MI: The University of Michigan Press.

[12] Dam, T. G., Volman, M., \& Wardekker, W. (2004). Making sense through participation: social differences in learning and identity development. In J. van der Linden, \& P. Renshaw (Eds.). Dialogic learning. Dordrecht: Kluwer.

[13] De Boo, M. (1999). Enquiring children, challenging teaching. Buckingham: Open University Press.

[14] Dudley-Evans, T., \& St John, M. (1998). Developments in ESP: A multi-disciplinary approach. Cambridge: Cambridge University Press.

[15] Ennis, R. H. (1996). Critical thinking. New Jersey: Prentice Hall.

[16] Flippo, R. F., \& Caverly, D. C. (2008). Handbook of college reading and study strategy research. New York: the Guilford Press. Taylor \& Francis.

[17] Frederiksen, J. R., \& Collins, A. (1989). A systems approach to educational testing. Educational Researcher. 18 (9), $27-32$.

[18] Gabennesch, H. (2006). Critical Thinking. What Is It Good For? Skeptical Inquirer. 30 (2), 36-41.

[19] Gardner, J. N., \& Jeweler, A. J. (2000). Your college experience: strategies for success (4th ed.). Belmont: Wadsworth.

[20] Grabe, W. (1991). Current Development in Second Language Reading Research. TESOL Quarterly. 25 (3), 375-406.

[21] Hernàndez-Laboy, O. I. (2009). Reading strategies ESL teachers utilize to enhance comprehension in students: Implications for classroom practices. Published Dissertation, Puerto Rico: College of Education University.

[22] Huckin, T. N. (1997). Critical discourse analysis. In T. Miller (Ed.), Functional approaches to written text: Classroom applications (pp. 78-92). Washington, DC: United States Information Agency.

[23] Huddleston, R. D., \& Pullum, G. K. (2005). A student`s introduction to English grammar. Cambridge: Cambridge University Press.

[24] Johnson, K., \& Johnson, H. (1998). Encyclopedic dictionary of applied linguistics. Oxford: Blackwell Publishers.

[25] Kim, D., \& Hall, J. K. (2002). The role of an interactive book reading program in the development of second language pragmatic competence. Modern Language Journal. 86 (3), 332-348.

[26] Kurland, D. (2000). How the language really works: The fundamentals of critical reading and writing. Retrieved 5 July 2006 from http://www. criticalreading.

[27] Liaw, M. (2007). Content-based reading and writing for critical thinking skills in an EFL context. English Teaching and Learning. 31 (2), 45-87.

[28] Lochhead, J., \& Whimby, A. (1987). Teaching Analytic Reasoning Through Think-Aloud Pair Problem Solving. In J. E. Stice (Ed.). Developing Critical Thinking and Problem-Solving Abilities. New Directions for Teaching and Learning, No. 30. San Francisco: Jossey-Bass.

[29] Masters, K. (2005). Role development in professional nursing practice. London. Jones \& Bartlett Learning.

[30] Mawter, J. (2007). All You Need to Teach: Critical Thinking, Humor and Text: For Ages 5-8. Macmillan Education Aus.

[31] Mc Namara, D. S. (2007). Reading comprehension strategies: theories, interventions, an Technologies. New York: Routledge.

[32] Mc Peck, J. E. (1991). Critical thinking and education. NY: St. Martin's Press.

[33] Messick, S. (1989). Validity. In R. L. Linn (Ed.). Educational measurement (3rd ed., pp. 13-103). New York: MacMillan.

[34] Montte, D. R., Sullivan, T. J., \& DeJong, C.R. (2010). Applied Social Research: A Tool for the Human Services. Cengage Learning.

[35] Moon, J. (2008). Critical Thinking of Theory and Practice. UK: Library of Congress. 
[36] Moorman, K., \& Ram, A. (1994). Integrating Creativity and reading: A functional approach. Proceedings of the Sixteenth Annual Conference of the Cognitive Science Society: Cognitive Science Program. Georgia Institute of Technology. Hillsdale, NJ: Lawrence Erlbaum Associates.

[37] Nist, S.L., \& Mealey, D.L. (1991). Teacher-directed comprehension strategies. In R. Flippo, \& D. Caverly (Eds.). Teaching reading and study strategies at the college level. Newark, DE: International Reading Association.

[38] Oxford, R. L. (2001). Language learning styles and strategies. In Teaching English as A Second or Foreign Language. Boston: Heinle \& Heinle Press.

[39] Pakhare, J. (2007). Effective Teaching: Reading Comprehension Strategies. Available at www.buzzle.com

[40] Paul, R., \& Elder, L. (2006). How to read a paragraph: The Art of Close Reading ( $2^{\text {nd }}$ ed). Foundation for Critical Thinking. www.criticalthinking.org. Ringo, S.

[41] Peterson`s (2008). Master Critical Thinking for the SAT. Peterson`s.

[42] Phan, N. (2006). Effective Reading. Asian EFL Journal, 15 (1), 1. Available at www.asian-efljournal.com/pta_october_06_np.php

[43] Pithers, R. T., \& Soden, R. (2000). Critical thinking in education: A review. Educational Research. 42 (3), $237-249$.

[44] RAND Reading Study Group, (2002). Reading for understanding: Toward an R \&D program in reading comprehension. Santa Monica, CA: RAND.

[45] Riazi, A. M. (2003). What do textbook evaluation schemes tell us? A study of the textbook evaluation schemes of three decades. In W. A . Renanda. (Ed.). Methodology and materials design in language teaching (pp. 52-68). Singapore: SEAMEO Regional Center.

[46] Rubenfeld, M. G., \& Scheffer, B. K. (2010). Critical thinking tactics for nurses: achieving the IOM competencies. Sudbury, MA: Jones \& Barlett Learning.

[47] Rubinstein, M. F., \& Firstenberg, I. R. (1987). Tools for Thinking. In J. E. Stice (Ed.), Developing Critical Thinking and Problem-Solving Abilities. New Directions for Teaching and Learning, No. 30. San Francisco: Jossey-Bass.

[48] Schafersman, S. D. (1991). An introduction to critical thinking. Retrieved January 1, 2010 from: www.freeenquiry/criticalthinking.html

[49] Schooten, E. V., \& Glopper, D. K. (2003). The development of literary response in secondary education. Poetics, 31(3), 155187. http://www.criticalthinking.org/university/univclass/Defining.htm

[50] Simpson, E. (2002). Critical thinking in nursing education: A literature review. Queensland, Australia.

[51] Spolsky, B. (1998). Conditions for Second Language Learning: Introduction to a Genera Theory. New York: Oxford University Press.

[52] Sweet, A. P., \& Snow, C. E. (Eds.) (2003). Rethinking reading comprehension. New York: Guilford.

[53] Tomlinson, B. (2001). Materials Development. In Carter, R. \& D. Nunan (Eds.). The Cambridge guide to teaching English to speakers of other languages (pp. 66-71). Cambridge: Cambridge University Press.

[54] Van Lier, L., \& Corson, D. (1997). Knowledge about language. Springer.

[55] Wallace, C. (2003). Critical reading in language education. Palgrave Macmillan.

[56] Waters, A. (2006). Thinking and language learning. ELT Journal, 60 (4), 237-319.

[57] Willingham, D. (2006). The Usefulness of Brief Instruction in Reading Comprehension Strategies. American Educator Journal.25(1), 42-43.

[58] Willsen, J., \& Binker, A. J. A. (1993). Critical thinking: Identifying the Targets. In R. W. Paul (Ed.). Critical thinking: What Every Person Needs to Survive in a Rapidly Changing World (pp. 17-36). Santa Rosa, CA: Foundation for Critical Thinking.

[59] Woods, D. R. (1987). How Might I Teach Problem Solving? In J. E. Stice (Ed.). Developing Critical Thinking and ProblemSolving Abilities. New Directions for Teaching and Learning, No. 30. San Francisco: Jossey-Bass.

[60] Yeh, S. S. (2001). Tests Worth Teaching To: Constructing State-Mandated Tests that Emphasize Critical Thinking. Educational Researcher. 3 (9), 12-17.

[61] Zahorik, J. A. (1995). Constructivist Teaching. Bloomington, Indian: Phi Delta Kappa Educational Foundation. http://www.epinet.org/content.cfm/books_teacher_quality_execsum_intro

Mohammad Reza Talebinejad is an Associate Professor of Applied Linguistics at Islamic Azad University, Shahreza Branch in Iran. He received his PhD from Shefield University, UK, his MA from the University of Texas at Austin, USA, and his BA from Isfahan University, Iran. He is currently teaching courses at $\mathrm{PhD}$ and MA levels at different universities in Iran.

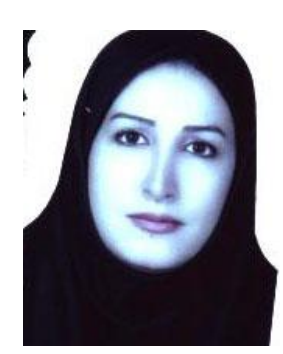

Zahra Matou graduated with an MA in Teaching English as a second language from Sheikhbahee University, Isfahan, Iran. She is currently teaching English courses at different universities and language institutes in Iran. 